\title{
The Evolution of Treasury Cash Management during the Financial Crisis
}

\author{
Paul J. Santoro
}

The U.S. Treasury and the Federal Reserve System have long enjoyed a close relationship, each helping the other to carry out certain statutory responsibilities. This relationship proved beneficial during the 2008-09 financial crisis, when the Treasury altered its cash management practices to facilitate the Fed's dramatic expansion of credit to banks, primary dealers, and foreign central banks.

ike most households and businesses, the U.S. Treasury maintains a cash balance to buffer short-run fluctuations in receipts and disbursements. Unlike most households, however, the Treasury's cash balance is highly volatile: between January 1,2006, and December 31,2010, it varied from as little as $\$ 3.1$ billion to as much as $\$ 188.6$ billion (Chart 1$){ }^{1}$

The Treasury divides its cash balance between two types of accounts: a Treasury General Account (TGA) at the Federal Reserve and Treasury Tax and Loan Note accounts (TT\&L accounts) at private depository institutions. ${ }^{2}$ The behavior of the respective account balances changed dramatically in the fall of 2008. As shown in Chart 2, prior to the financial crisis that followed the collapse of Lehman Brothers on September 15, 2008 (hereafter, "the crisis"), the TGA mostly fluctuated in a narrow band around $\$ 5$ billion while TT\&L balances varied more widely. ${ }^{3}$ In contrast, since the fall of 2008, TT\&L balances have fluctuated in a narrow band around $\$ 2$ billion and the TGA has varied widely.

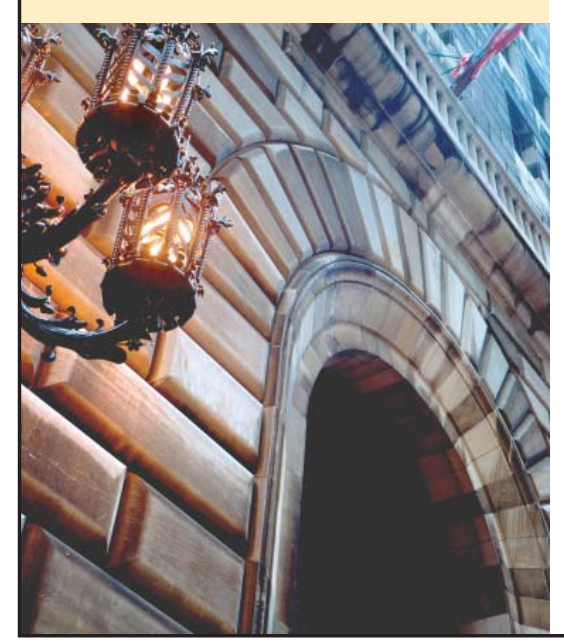

\footnotetext{
${ }^{1}$ We define the Treasury's cash balance as the difference between the Total Operating Balance and the Supplementary Financing Program Account as shown on the Daily Treasury Statement.

${ }^{2}$ The Federal Reserve maintains the TGA as part of its statutory obligation to serve as fiscal agent of the United States (Manypenny and Bermudez 1992). The TGA has existed since January 1916 (1916 Treasury Annual Report, p. 6); TT\&L accounts, originally named "Liberty Loan deposit accounts," have existed since May 1917 (Treasury Circular no. 79, May 16, 1917, reprinted in 1917 Treasury Annual Report, p. 131; Treasury Circular no. 81, May 29, 1917, reprinted in 1917 Treasury Annual Report, p. 124).

${ }^{3}$ While the start date of the financial crisis is debatable and may have been as early as 2007, the effect of the crisis on Treasury cash management coincided with the rapid expansion of the Federal
} Reserve's balance sheet after the collapse of Lehman Brothers in September 2008. 
Chart 1

Treasury Cash Balances

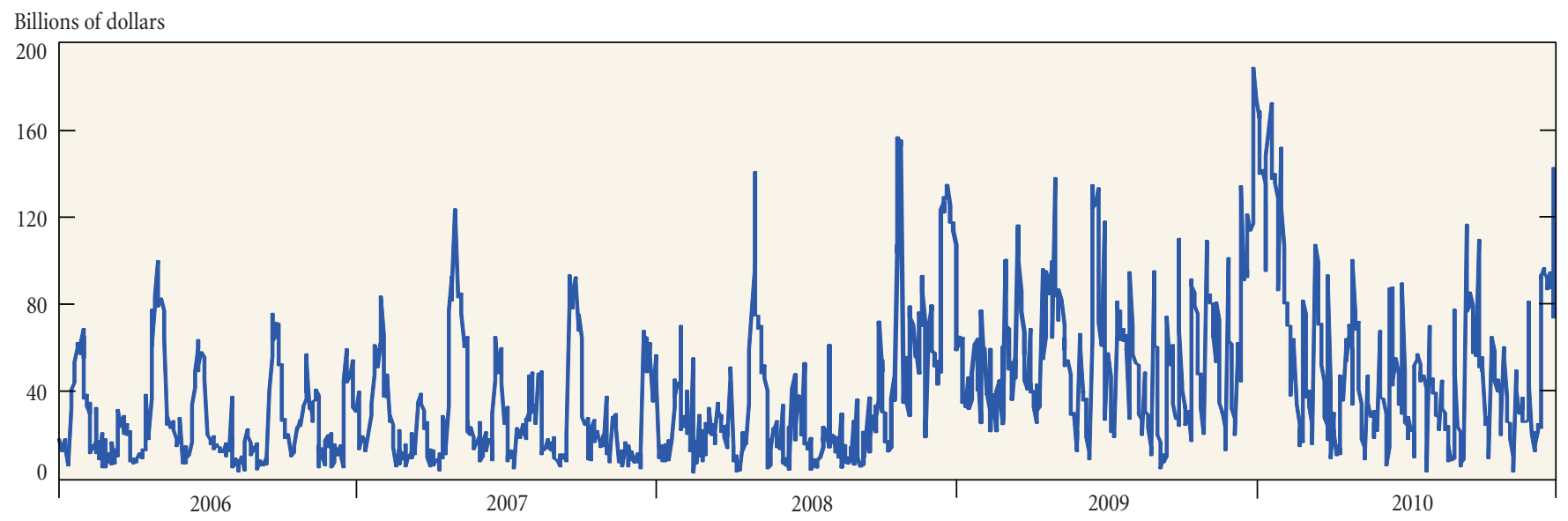

Sources: U.S. Department of the Treasury, Daily Treasury Statement; authors' calculations.

Note: Cash balances are computed as the difference between the Total Operating Balance and the Supplementary Financing Program Account as shown on the Daily Treasury Statement.

\section{Balances in the Treasury General Account and Treasury Tax and Loan Note Accounts}

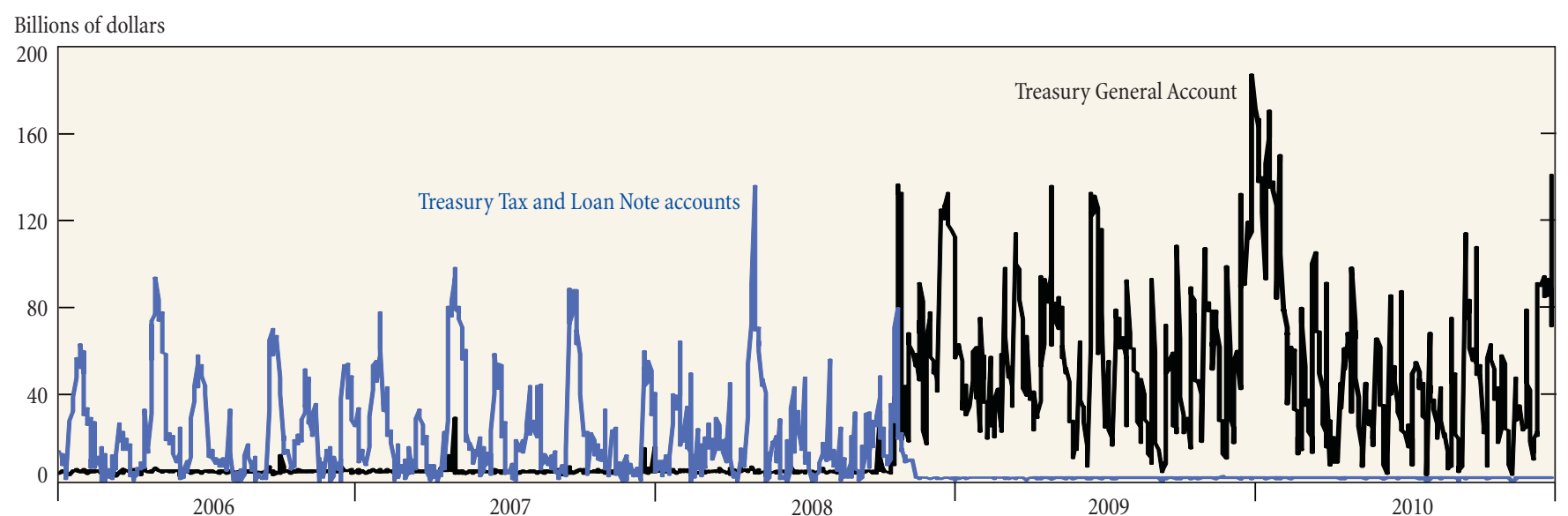

Source: U.S. Department of the Treasury, Daily Treasury Statement.

This edition of Current Issues, one of a group of articles describing Federal Reserve responses to the crisis, ${ }^{4}$ explains how a change in Federal Reserve credit policy during the crisis was associated with the change in Treasury cash manage-

${ }^{4}$ See also Armantier, Krieger, and McAndrews (2008), Adrian, Burke, and McAndrews (2009), Fleming, Hrung, and Keane (2009), Garbade, Keane, Logan, Stokes, and Wolgemuth (2010), Adrian, Kimbrough, and Marchioni (2011), Gagnon, Raskin, Remache, and Sack (2011), and Goldberg, Kennedy, and Miu (2011). ment practices shown in Chart 2. Understanding the relationship between Federal Reserve credit policy and Treasury cash management is important because the relationship illuminates an important but sometimes unappreciated interface between the Treasury and the Fed. It also underscores the symbiotic relationship between the two institutions, in which each assists the other in fulfilling its statutory responsibilities.

Subsequent sections of this article will detail the changes in Federal Reserve operating procedures and Treasury cash 
management during the crisis. The first section, however, presents a framework for the analysis by reviewing the core missions of the Treasury and the Federal Reserve and explaining how each institution seeks to fulfill its mandate.

\section{The Missions of the U.S. Treasury and the Federal Reserve}

\section{The Treasury}

A principal mission of the U.S. Treasury is collecting income taxes and other taxes prescribed by statute and funding the financial commitments of the U.S. government. ${ }^{5}$ In the course of fulfilling this mandate, the Treasury undertakes a variety of debt management operations, including refinancing maturing debt with new issues, selling additional debt when expenditures exceed revenues, and retiring debt when the reverse is true. As noted earlier, the Treasury maintains accounts at the Federal Reserve and at private depository institutions to buffer day-to-day fluctuations in cash flows that cannot be accommodated efficiently with debt management operations.

\section{The Federal Reserve}

A principal mission of the Federal Reserve System is managing the U.S. money supply and credit market conditions to promote maximum employment with stable prices and moderate longterm interest rates. ${ }^{6}$ Prior to the fall of 2008 , the Fed sought to carry out this mandate primarily by (1) targeting the interest rate on overnight loans in the federal funds market and (2) managing the supply of reserves available to the banking system to stabilize the federal funds rate at the target rate. Officials purchased (sold) Treasury securities, either outright or through repurchase agreements, ${ }^{7}$ when they wanted to add (drain) reserves to keep the funds rate from rising above (falling below) the target.

In the course of responding to the crisis, the Fed provided unprecedented quantities of central bank credit to banks, primary dealers, foreign central banks, and others. The increase in assets on the Fed's balance sheet generated a corresponding increase in central bank liabilities. Currency in circulation expanded modestly, from $\$ 835$ billion on September 10, 2008, to $\$ 890$ billion at the end of the year, but deposits at the central bank ballooned from $\$ 38$ billion to $\$ 1.2$ trillion, ${ }^{8}$ far beyond what depository institutions were required to hold. As described below, the Fed and the Treasury adopted a variety of novel procedures

\footnotetext{
${ }^{5}$ See "Duties and Functions of the U.S. Department of the Treasury," available at www.treasury.gov/about/role-of-treasury/Pages/default.aspx.

${ }^{6}$ See Board of Governors of the Federal Reserve System (2005, p. 1).

${ }^{7} \mathrm{~A}$ repurchase agreement is a sale of securities coupled with an agreement to repurchase the same securities at a specified price on a later date. Repurchase agreements are also called "repos."

${ }^{8}$ Deposits at the central bank include reserve balances of depository institutions, U.S. Treasury deposits, foreign official deposits, and service-related deposits (including required clearing balances and adjustments to compensate for float).
}

to prevent the expanding quantity of reserves from driving the federal funds rate to zero.

\section{The Interface between the Federal Reserve and the Treasury} At first impression, the Federal Reserve and Treasury mandates might seem sufficiently distinct that the two institutions should be able to function independently of each other. However, the Treasury funnels most of its receipts into, and it disburses most of its payments from, the TGA. Thus, there is a continuous flow of funds from private depository institutions to the TGA and back again. During fiscal year 2010, $\$ 11.6$ trillion flowed into, and then out of, the TGA.

Flows of funds between the TGA and private depository institutions were important prior to the crisis because the TGA is maintained on the books of the Federal Reserve; increases in TGA balances stemming from Treasury net receipts drained reserves from the banking system and, in the absence of offsetting actions, put upward pressure on the federal funds rate. Conversely, decreases in TGA balances resulting from Treasury net expenditures added reserves to the banking system and, absent offsetting actions, put downward pressure on the funds rate. This dynamic created an important interface between Treasury and Federal Reserve operations. The sections that follow describe first how Treasury and Federal Reserve officials cooperated to manage the interface before the crisis, and then how the interface has changed since the onset of the crisis and the expansion of the Fed's balance sheet.

\section{Treasury Cash Management before the Crisis}

If, in the pre-crisis regime, the Treasury had deposited all of its receipts in the TGA as soon as they came in, and if it had held the funds in the TGA until they were disbursed, the supply of reserves available to the banking system - and hence the overnight federal funds rate- would have exhibited undesirable volatility. To dampen the volatility, the Fed would have had to conduct frequent and large-scale open market operations, draining reserves when TGA balances were declining and adding reserves when TGA balances were rising. ${ }^{9} \mathrm{~A}$ more efficient strategy, and the one used by the Treasury in its Tax and Loan program, was to seek to maintain a stable TGA balance.

\section{The Treasury Tax and Loan Program}

Prior to the onset of the crisis, the Treasury Tax and Loan program had three principal objectives: processing federal tax

\footnotetext{
${ }^{9}$ This actually happened between 1974 and 1978. During this period, the TGA experienced large fluctuations when the Treasury sought to limit aggregate TT\&L balances to about $\$ 1.5$ billion (Lovett 1978, p. 43), and the Federal Reserve was obliged to conduct correspondingly large and frequent open market operations (Brockschmidt 1975; McDonough 1976). The need for aggressive intervention ended in 1978 following a major reorganization of the TT\&L program (Lovett 1978; Lang 1979).
} 
receipts, stabilizing the TGA balance, and generating interest income for the Treasury. ${ }^{10}$

\section{Collecting Federal Tax Receipts}

A private depository institution could participate in the TT\&L program in any of three ways: as a collector institution, as a retainer institution, or as an investor institution.

A collector institution was a tax collection conduit. It accepted tax payments from businesses (primarily withholdings of personal income taxes, corporate income taxes, and social security contributions) in electronic form and at its teller windows and transferred the payments to the TGA.

A retainer institution also accepted tax payments but, subject to a limit specified by the institution and pledge of sufficient collateral, retained the payments in an interest-bearing "Main Account" until called for by the Treasury. If a Main Account balance exceeded the institution's limit, or if it exceeded the collateral value of the assets pledged by the institution, the excess was transferred promptly to the TGA.

An investor institution did everything a retainer institution did and, as described below, also accepted direct investments from the Treasury. ${ }^{11}$ The investments were credited to the institution's Main Account and had to be collateralized.

\section{Stabilizing the TGA Balance}

Before the onset of the crisis, the Treasury typically aimed to maintain a $\$ 5$ billion balance in the TGA. ${ }^{12}$ The Treasury used well-timed cash calls ${ }^{13}$ and direct investments to maintain the actual balance close to the target most of the time (see Chart 2).

Each morning Treasury cash managers and analysts at the Federal Reserve Bank of New York estimated the current day's receipts and disbursements. During a telephone conference call at 9 a.m., they combined the estimates with the previous day's closing TGA balance, scheduled payments of principal and interest, scheduled proceeds from sales of new securities, and other similar items to produce an estimate of the current day's closing balance. If the estimated closing balance exceeded the target, the Treasury would invest the excess at investor institutions

\footnotetext{
${ }^{10}$ Garbade, Partlan, and Santoro (2004) describe in more detail the Treasury Tax and Loan program as it operated before the crisis. The Treasury is presently in the midst of a major revamping of its cash management systems. See Financial Management Service, "Collections and Cash Management Modernization (CCMM)," available at www.fms.treas.gov/ccmm/index.html.

${ }^{11}$ A direct investment was a Treasury-directed transfer of funds from the TGA to Treasury's TT\&L accounts at investor banks.

12 The target balance, established in 1988, had to be large enough to provide a high degree of confidence that the TGA would not be overdrawn at the end of a business day since the Fed was not authorized to lend directly to the Treasury. The target balance was sometimes bumped up to $\$ 7$ billion when cash flows were unusually heavy, such as the intervals around tax payment dates.

${ }^{13}$ Cash calls are Treasury-directed transfers from TT\&L accounts to the TGA.
}

that had sufficient free collateral and room under their balance limits to accept additional funds. ${ }^{14}$ If the estimated balance was below target, the Treasury would call for funds from retainer and investor institutions to make up the shortfall.

\section{Earning Interest on TT\&L Balances}

The Treasury had three ways to earn interest on TT\&L balances. Conventional Main Account balances earned interest at the federal funds rate less 25 basis points. In addition, the Treasury could, at its discretion, make overnight investments in repurchase agreements (repos) and term investments through its Term Investment Option (TIO) program.

The relationship between the rate on Main Account balances and the federal funds rate was set in 1978, in the course of a major overhaul of the TT\&L program. A market-linked rate equal to the funds rate less 25 basis points was deemed appropriate for collateralized TT\&L balances because, at the time, it was approximately equal to the rate on overnight repurchase agreements on Treasury collateral. However, by the late 1990s, the spread between the federal funds rate and the repo rate had narrowed to 5 basis points and the Treasury began to consider alternatives to obtain a higher rate of return on investments.

The first alternative, the TIO program, was introduced on an experimental basis in April 2002 and made permanent in November $2003 .{ }^{15}$ A TIO auction was similar to a Treasury bill auction, but in reverse. The Treasury offered to invest (rather than borrow) a specified amount of money for a specified term and participating institutions bid on the money. On average from March 2006 to March 2007, institutions were willing to pay about 18 basis points more for TIO balances than they had to pay on Main Account balances, ${ }^{16}$ in part because TIO balances would remain with the institution for a specified term rather than being subject to daily calls.

In March 2006, the Treasury initiated a pilot program of investing excess funds through overnight repurchase agreements. During the pilot program, the Treasury invested an average of $\$ 2.7$ billion per day in repurchase agreements against Treasury collateral. Daily offerings ranged between $\$ 500$ million and $\$ 6$ billion. ${ }^{17}$ On average from March 2006 to March 2007,

\footnotetext{
14 Occasionally, net flows into the TGA were so large that the Treasury exhausted the capacity of investor institutions to accept additional funds and TGA balances rose above the target level by more than several billion dollars. For more on stabilizing the TGA and the timing of direct investments and calls, see, for example, the discussion of the April 2000 tax payments in Garbade, Partlan, and Santoro (2004, p. 6).

${ }^{15}$ See, Garbade, Partlan, and Santoro (2004) and Hrung (2007).

${ }^{16}$ Government Accountability Office (2007, p. 13, Table 2).

${ }^{17}$ U.S. Department of the Treasury, Financial Management Service, "Repurchase Agreement (Repo) Program," available at http://www.fms.treas.gov/tip/repo/ index.html.
} 


\section{Allocation of Treasury Tax and Loan Balances among Term Investment Option Balances, Coventional Main Account Balances, and Repurchase Agreements prior to September 15, 2008}

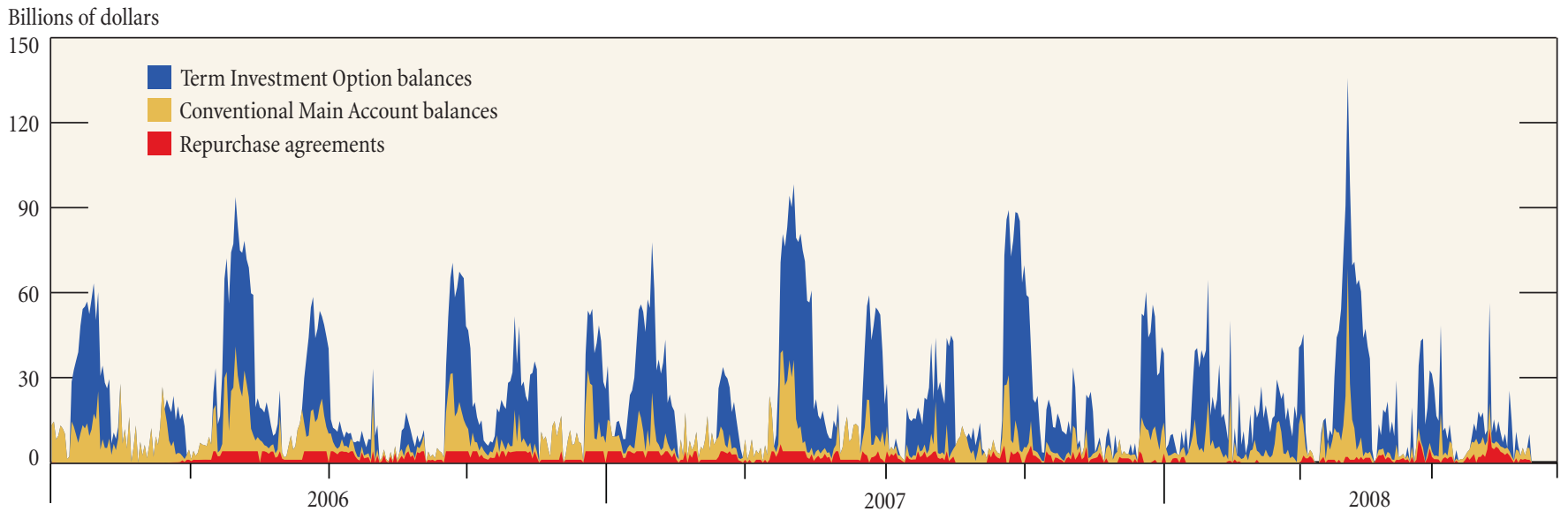

Sources: U.S. Department of the Treasury, Daily Treasury Statement; authors' calculations.

institutions were willing to pay about 21 basis points more for repo balances than they had to pay on Main Account balances, ${ }^{18}$ in part for the enhanced certainty of obtaining and retaining funds until the next business day.

Chart 3 shows how TT\&L balances were divided among conventional Main Account balances, TIO investments, and repo investments prior to the crisis.

\section{Treasury Cash Management following the Onset} of the Crisis: The Initial Structure

It quickly became clear during the week of September 15, 2008, that the United States was heading into a major financial crisis. On Tuesday, September 16, a $\$ 63$ billion money market mutual fund "broke the buck" and turned what had been a slow leakage of shareholder balances into a full-scale run. ${ }^{19}$ Later the same day, the Board of Governors of the Federal Reserve System, acting "with the full support of the Treasury Department," authorized the Federal Reserve Bank of New York to lend up to $\$ 85$ billion to American International Group, Inc. (AIG). ${ }^{20}$

\footnotetext{
${ }^{18}$ Government Accountability Office (2007, p. 13, Table 2).

19 Investment Company Institute (2009). A money market mutual fund is said to break the buck when its net asset value falls below $\$ 0.995$ per share. In that case, the fund has to begin to redeem its shares at net asset value or otherwise act to ensure fair treatment of its shareholders.

${ }^{20}$ Board of Governors of the Federal Reserve System, press release, September 16, 2008; U.S. Department of the Treasury, "Statement by Secretary Henry M. Paulson, Jr., on Federal Reserve Actions surrounding AIG," press release, September 16, 2008.
}

By the close of business on Wednesday, September 17, AIG had borrowed $\$ 28$ billion, primary dealers had borrowed $\$ 60$ billion (through the Primary Dealer Credit Facility ${ }^{21}$ ), and depository institutions had added $\$ 10$ billion to their discount window borrowings. In all, Federal Reserve credit expanded by $\$ 100$ billion in just two days, and there was more to come. ${ }^{22}$

As a result of the Fed's mushrooming loan portfolio, reserve balances of depository institutions increased from $\$ 25$ billion on September 10 to $\$ 82$ billion on September 17. It was clear that, in the absence of profound institutional change, reserve balances were going to be vastly in excess of requirements for the foreseeable future and federal funds were going to trade well below the target rate of 2 percent. ${ }^{23}$

\footnotetext{
${ }^{21}$ Adrian, Burke, and McAndrews (2009) explain the origins and operation of the Primary Dealer Credit Facility.

22 On September 18, the Board of Governors announced that it had agreed to expand its swap lines with foreign central banks by $\$ 180$ billion (Board of Governors of the Federal Reserve System, press release, September 18, 2008). Several counterparties promptly expanded their draws of U.S. dollars by \$64 billion (Board of Governors of the Federal Reserve System, press release, December 1, 2010). On September 19, the Board announced the formation of the Asset-Backed Commercial Paper Money Market Mutual Fund Liquidity Facility (Board of Governors of the Federal Reserve System, press release, September 19, 2008). The facility opened for business on Monday, September 22 , and within three days lent $\$ 73$ billion.

${ }^{23}$ The Federal Reserve Bank of New York's annual report of domestic open market operations in 2008, prepared by the Bank's Markets Group, notes that "after September 15, [2008], the magnitude of liquidity added to the system through various programs exceeded the Federal Reserve's ability to offset with draining operations" (Federal Reserve Bank of New York 2009, p. 6).
} 


\section{The Supplementary Financing Program}

The first Treasury cash management change following the onset of the crisis involved the sale of Treasury bills by the U.S. Treasury and the deposit of the proceeds with the Federal Reserve-actions that drained reserves from the banking system and reduced the volume of excess reserves. On Wednesday, September 17, the Treasury announced the initiation of "a temporary Supplementary Financing Program [SFP] at the request of the Federal Reserve." 24 The announcement stated that the program would "consist of a series of Treasury bills, apart from Treasury's current borrowing program, which will provide cash for use in the Federal Reserve [lending and liquidity] initiatives." ${ }^{25}$ The Treasury announced three SFP sales that day for a total of $\$ 100$ billion. The proceeds from the sales were deposited in a newly created SFP account at the Fed, thereby draining approximately $\$ 100$ billion of reserves from the banking system.

By Friday, October 3, two weeks and two days after the start of the Supplementary Financing Program, the Treasury had issued eleven SFP bills (one of which was to refinance a maturing SFP bill) and the program had drained about $\$ 355$ billion of reserve balances. SFP bills peaked at $\$ 560$ billion between October 20 and November 12 (Chart 4).

On October 6, the Federal Reserve announced that it would begin to pay interest on reserve balances effective Thursday, October 9 . This new feature of monetary policy was expected to allow the Fed to continue to use its lending program to address conditions in credit markets while also maintaining the funds rate close to the target level, even in the absence of the SFP program. ${ }^{26}$

${ }^{24}$ U.S. Department of the Treasury, “Treasury Announces Supplementary Financing Program," press release, September 17, 2008. Emphasis added.

${ }^{25}$ The novelty of the SFP program led to some confusion in describing the program. The New York Times, for example, reported the first sale of SFP bills by stating, "In a sign of how short the Fed's available reserves had become, the Treasury Department sold tens of billions of dollars of special 'supplementary' Treasury bills on September 17 to provide the Fed with extra cash" ("A New Role for the Fed: Investor of Last Resort," New York Times, September 18, 2008, p. A1). In fact, the Federal Reserve can emit currency and create bank reserves at will and thus did not need any "extra cash." What it could not fashion from its existing authorities was a way to drain massive quantities of reserves from the banking system. The Wall Street Journal got it right when it stated that the Treasury was "carrying out [a reserve] draining function in place of the Fed" ("U.S. Moves to Bolster Fed Balance Sheet - Treasury Auctions $\$ 40$ Billion of Debt; More Sales on Tap," Wall Street Journal, September 18, 2008, p. A3).

${ }^{26}$ See Board of Governors of the Federal Reserve System, press release, October 6, 2008: "The payment of interest on excess reserves will permit the Federal Reserve to expand its balance sheet as necessary to provide the liquidity necessary to support financial stability while implementing the monetary policy that is appropriate in light of the System's macroeconomic objectives of maximum employment and price stability." See also Federal Reserve Bank of New York (2009, p. 4): "In theory, the payment of interest on excess reserve balances allows the Federal Reserve to continue to use its lending programs to address conditions in the credit markets while also maintaining the fed funds rate close to the target established by the FOMC."
Chart 4

\section{SFP Bills Outstanding \\ Through December 29, 2009}

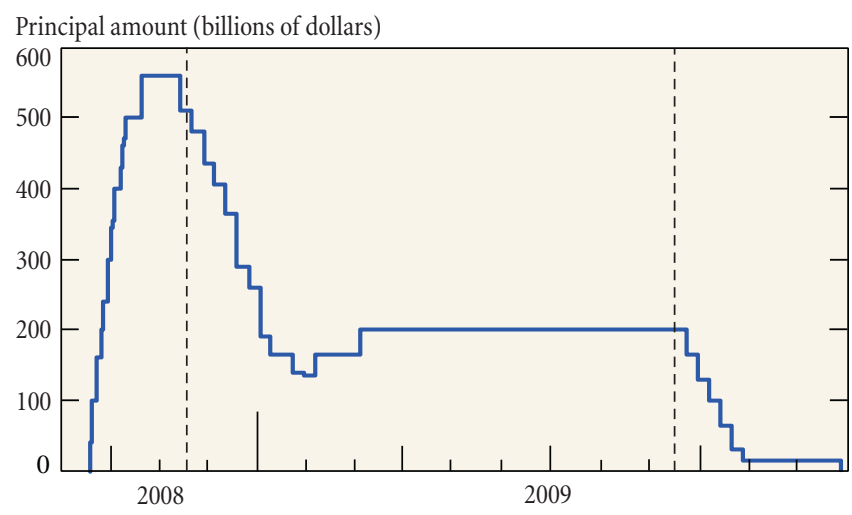

Source: U.S. Department of the Treasury.

Notes: SFP is Supplementary Financing Program. The first vertical dashed line in the chart marks the November 17,2008, announcement by the Treasury that it would be reducing the size of the SFP program. The second vertical dashed line marks the September 16, 2009, announcement by the Treasury that it would begin to redeem, rather than refinance, maturing SFP bills.

On November 17 the Treasury announced that it was trimming the size of the SFP program. ${ }^{27}$ By the end of 2008, there were $\$ 260$ billion of SFP bills outstanding. The program stabilized at \$200 billion in early March 2009 and remained at that level until late September 2009, when the Treasury began to redeem maturing bills for cash in anticipation of a debt ceiling constraint. ${ }^{28}$ The last SFP bill issued in the course of the original program was redeemed on December 29, 2009. ${ }^{29}$

The tenor-or term to maturity—of SFP bills issued in 2008 and 2009 ranged from just 7 days to as many as 101 days in the first two months of the program, but stabilized at 70 days in 2009 when the overall size of the program firmed at $\$ 200$ billion (Chart 5). Most SFP bills were issued to refinance maturing SFP bills; in only two instances in 2009 was an SFP bill issued for new

\footnotetext{
${ }^{27}$ U.S. Department of the Treasury, “Treasury Issues Debt Management Guidance on the Temporary Supplementary Financing Program," press release, November 17, 2008.

${ }^{28}$ See U.S. Department of the Treasury, "Treasury Issues Debt Management Guidance on the Supplementary Financing Program, press release, September 16, 2009; "U.S. Treasury to Scale Back Fed Program to Avoid Debt Ceiling," Bloomberg .com, September 16, 2009; and "Treasury to Shrink Financing Program," Wall Street Journal, September 16, 2009, p. A3.

${ }^{29}$ On December 28, 2009, Congress raised the debt ceiling by $\$ 290$ billion. Armed with enlarged issuance authority, the Treasury revived the Supplementary Financing Program. The revived program ran from the end of 2009 to mid-2011, when it was allowed to run down in the face of another debt ceiling constraint. For most of that time, the Treasury regularly and predictably auctioned $\$ 25$ billion of eight-week SFP bills every week.
} 
Chart 5

\section{Tenor of SFP Bills Issued in 2008 and 2009}

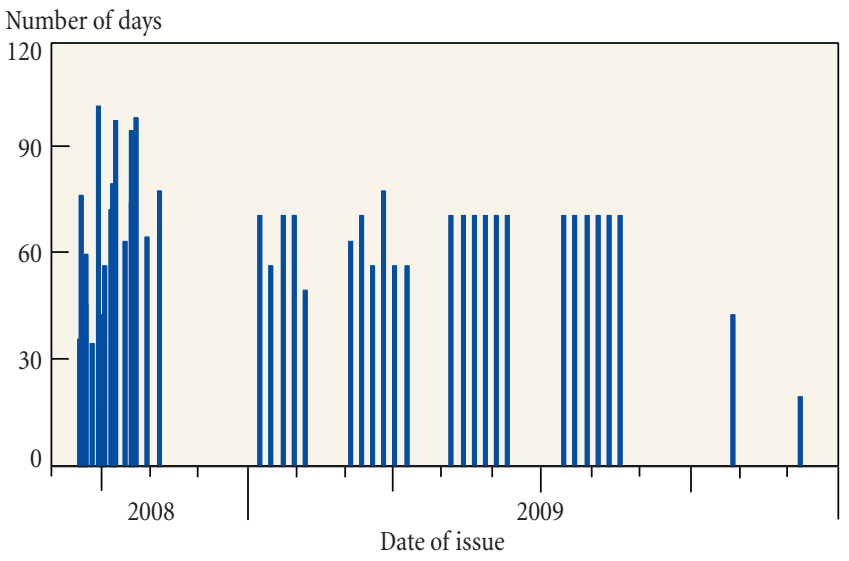

Source: U.S. Department of the Treasury.

Note: SFP is Supplementary Financing Program.

Chart 6

\section{Size of SFP Bills Issued in 2008 and 2009}

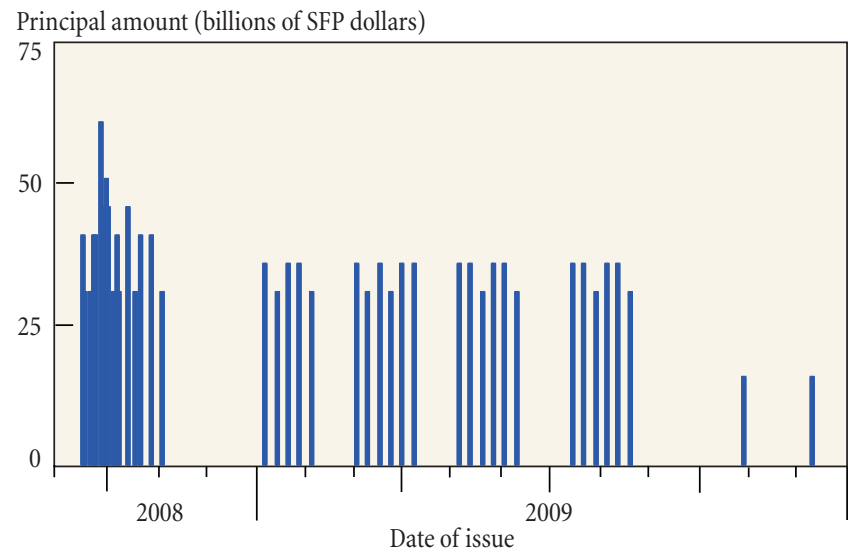

Source: U.S. Department of the Treasury.

Note: SFP is Supplementary Financing Program.

cash. The size of the SFP bills issued in 2008 and 2009 initially ranged from $\$ 30$ billion to $\$ 60$ billion, but stabilized at $\$ 30$ billion to $\$ 35$ billion in 2009 (Chart 6).

\section{Treasury Cash Management after the Fed Began}

Paying Interest on Reserves

On October 6, 2008, when the Federal Reserve announced that it would begin to pay interest on reserves, it stated that it would
Chart 7

Target Federal Funds Rate, IOER Rate, and Federal Funds Rate

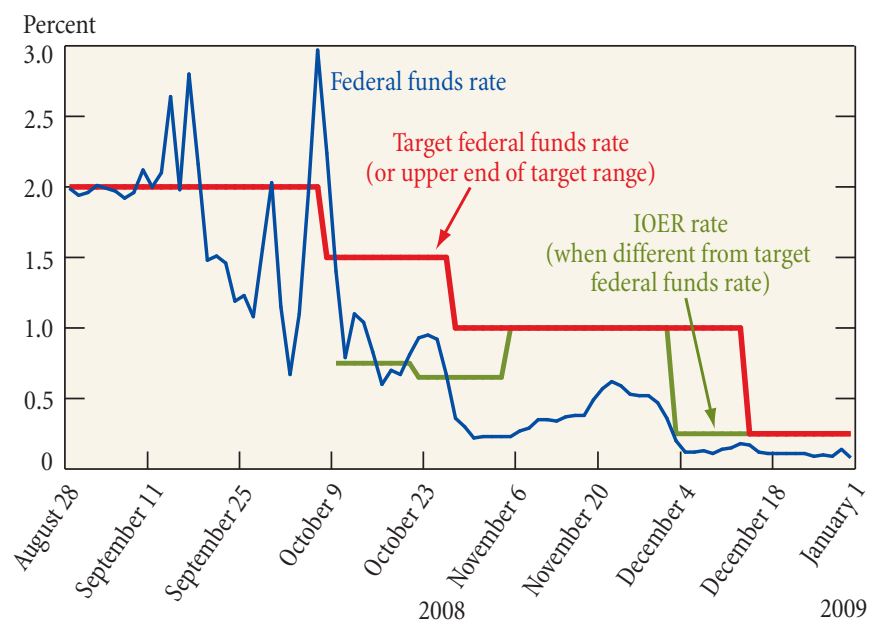

Sources: Board of Governors of the Federal Reserve System; Federal Reserve Bank of New York.

Notes: IOER is the interest rate on excess reserves. Days marked on the horizontal axis denote the beginnings of reserve maintenance periods.

pay the average target federal funds rate over a reserve maintenance period, less 10 basis points, on required reserves and the lowest target rate over a maintenance period, less 75 basis points, on excess reserves. ${ }^{30}$ Following several changes in the target funds rate and the rate paid on required reserve balances and excess balances, the FOMC established (on December 16, 2008) a target range of zero to 25 basis points for the funds rate, and the Board of Governors announced a rate of 25 basis points on reserve balances. ${ }^{31}$ (The rate of interest on excess reserves is commonly known as the "IOER rate.") Charts 7 and 8 show that the federal funds rate was persistently below the IOER rate from late 2008 through 2010.

\section{Consequences for Treasury Cash Management}

The structure of interest rates after December 2008 prompted the Treasury to make a second change in its cash management practices since it now had an economic incentive to keep its cash balances in the Treasury General Account rather than in Treasury Tax and Loan Note accounts. When the overnight federal funds rate fell below 25 basis points, the TT\&L rate on Main Account balances went to zero and the likely rates of

\footnotetext{
${ }^{30}$ Board of Governors of the Federal Reserve System, press release, October 6, 2008.

${ }^{31}$ Board of Governors of the Federal Reserve System, press release, December 16, 2008.
} 
Chart 8

\section{IOER Rate and Federal Funds Rate}

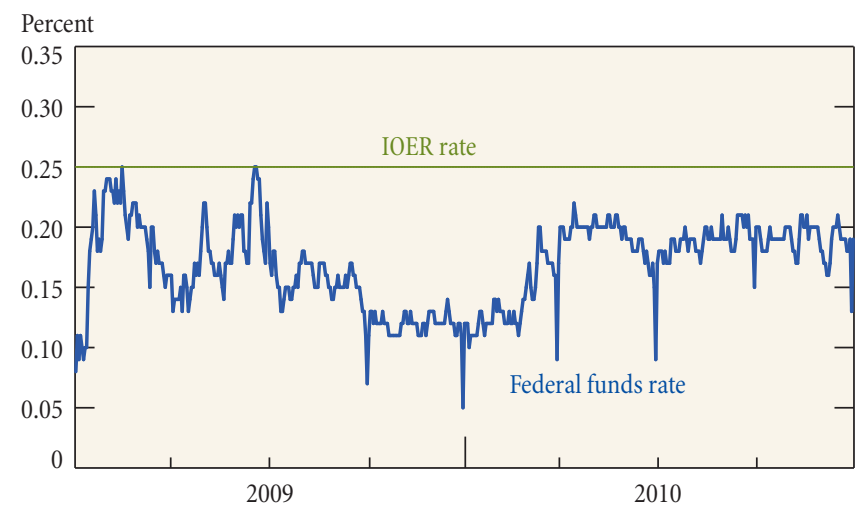

Sources: Board of Governors of the Federal Reserve System; Federal Reserve Bank of New York.

Note: The IOER rate is the interest rate on excess reserves.

interest on TIO balances and Treasury repurchase agreements fell below 25 basis points. In that environment, it was more remunerative for the Treasury to keep its money in the TGA. Shifting Treasury balances to private depositories would have increased the reserve balances of depository institutions and required the Fed to pay interest on those reserve balances (at the IOER rate of 25 basis points per annum). This would have reduced Federal Reserve payments to the Treasury (of Federal Reserve earnings in excess of expenses) by more than what the Treasury could earn from the depositories. ${ }^{32}$ In addition, a large TGA balance limited the risk that the Treasury might overdraw the account at a time when expenditures were extraordinarily volatile.

At the same time, the volatile swings in TGA balances associated with the decision to keep essentially all of the Treasury's operating cash balances in the TGA (see Chart 2) did not cause a problem for the Fed because the swings did not result in any comparable volatility in the federal funds rate. In particular, expanding TGA balances did not reduce the quantity of reserves available to the banking system to a level at all close to what banks wanted or were required to hold and thus did not put upward pressure on the funds rate.

\section{Consequences for the Supplementary Financing Program} In principle, paying interest on reserves could have led the Treasury to terminate the Supplementary Financing Program. Adhering to its November 17,2008, announcement, the Treasury

\footnotetext{
32 However, the Treasury continued to keep \$2 billion in TT\&L accounts until December 29,2011, to ensure that the functionalities of the TT\&L program remained intact in the event that the Fed returned to the pre-crisis structure of monetary policy. By 2012, collector and retainer designations were eliminated, and the TT\&L investment program was shut down. Treasury indicated that it planned on implementing a new investment program when market conditions warranted and that more details would be announced when they became available.
}

did reduce the size of the program, but it did not eliminate it entirely (Chart 4).

There were several reasons for not eliminating the Supplementary Financing Program at the end of 2008. First, SFP bills soaked up a nontrivial quantity of excess reserves. ${ }^{33}$ Second, higher SFP balances, like higher TGA balances, reduced the volume of reserves on which the Federal Reserve had to pay interest and were, therefore, fiscally beneficial to the Treasury. And third, the Supplementary Financing Program provided market participants with additional quantities of a short-term, credit risk-free instrument that was unusually attractive in the midst of the crisis. ${ }^{34}$

\section{Conclusion}

The Treasury Tax and Loan Note program has long been an exemplar of cooperation between the Federal Reserve and the Treasury, with the Fed serving as the Treasury's fiscal agent in maintaining the Treasury General Account and with the Treasury issuing cash calls and making direct investments to stabilize the TGA at a specified target level. The 2008-09 crisis triggered a further deepening of the close relationship between the two institutions. When the Fed's balance sheet ballooned in September 2008 as the crisis deepened, the Treasury announced, at the Fed's request, the Supplementary Financing Program to soak up excess reserves and to keep the federal funds rate from being driven down to zero. The subsequent introduction of interest on reserves left the Treasury free to abandon those aspects of the TT\&L program aimed at stabilizing the TGA and allowed it to pursue cash management practices that, in light of the new monetary regime, were in the best interest of taxpayers.

The Treasury's cash management and investment strategy continues to evolve, guided by the goals of earning a fair return on investment, ensuring that the funds available in the TGA are sufficent to avoid an overdraft, and avoiding interference with the implementation of monetary policy. When the interest rates that the Treasury receives on investments are higher, it may resume investing its surplus funds with the private sector, as it did prior to 2009 . However, if short-term interest rates remain close to current levels and there is no need to target the TGA, then Treasury investments are likely to remain low or nonexistent since holding funds in the TGA is more remunerative than investing funds with the private sector.

Nevertheless, a significant decline in excess reserves resulting from a shift in monetary policy may once again make it necessary to target a more stable TGA, so that TGA volatility does not cause

\footnotetext{
33 Bernanke (2009) observed that "issuance of [SFP] bills effectively drains reserves from the banking system, improving monetary control."

${ }^{34}$ Hrung and Seligman (2011, p. 7) noted that "an incidental by-product" of the SFP program "was that it increased the amount of high-quality collateral available in the market, helping to alleviate... supply-side stresses in the money markets..."
} 
undesirable federal funds rate volatility and interfere with the implementation of monetary policy.

The author thanks Kenneth Garbade for his many substantive contributions to the preparation of this article. He also thanks David Monroe, Warren Hrung, John Partlan, Gregory Till, and Chris Burke for helpful comments on earlier versions.

\section{References}

Adrian, Tobias, Christopher Burke, and James McAndrews. 2009.“The Federal Reserve's Primary Dealer Credit Facility." Federal Reserve Bank of New York Current Issues in Economics and Finance 15, no. 4 (August).

Adrian, Tobias, Karin Kimbrough, and Dina Marchioni. 2011. “The Federal Reserve's Commercial Paper Funding Facility." Federal Reserve Bank of New York Economic Policy Review 17, no. 1 (May): 25-39.

Armantier, Olivier, Sandra Krieger, and James McAndrews. 2008. “The Federal Reserve's Term Auction Facility." Federal Reserve Bank of New York Current Issues in Economics and Finance 14, no. 5 (July).

Bernanke, Ben. 2009. The Crisis and the Policy Response. Stamp Lecture, London School of Economics, London, England, January 13.

Board of Governors of the Federal Reserve System. 2005. The Federal Reserve System: Purposes and Functions.

Brockschmidt, Peggy. 1975. “Treasury Cash Balances.” Federal Reserve Bank of Kansas City Monthly Review 60, no. 7 (July-August): 12-20.

Federal Reserve Bank of New York. 2009. Domestic Open Market Operations during 2008. Available at www.newyorkfed.org/markets/omo/omo2008.pdf.

Fleming, Michael, Warren Hrung, and Frank Keane. 2009. “The Term Securities Lending Facility: Origin, Design, and Effects.” Federal Reserve Bank of New York Current Issues in Economics and Finance 15, no. 2 (February).

Gagnon, Joseph, Matthew Raskin, Julie Remache, and Brian Sack. "Large-Scale Asset Purchases by the Federal Reserve: Did They Work?” Federal Reserve Bank of New York Economic Policy Review 17, no. 1 (May): 41-59.
Garbade, Kenneth, Frank Keane, Lorie Logan, Amanda Stokes, and Jennifer Wolgemuth. 2010. "The Introduction of the TMPG Fails Charge for U.S. Treasury Securities." Federal Reserve Bank of New York Economic Policy Review 16, no. 2 (October): 45-71.

Garbade, Kenneth, John Partlan, and Paul Santoro. 2004. "Recent Innovations in Treasury Cash Management." Federal Reserve Bank of New York Current Issues in Economics and Finance 10, no. 11 (November).

Goldberg, Linda, Craig Kennedy, and Jason Miu. 2011. "Central Bank Dollar Swap Lines and Overseas Dollar Funding Costs." Federal Reserve Bank of New York Economic Policy Review 17, no. 1 (May): 3-20.

Government Accountability Office. 2007. Debt Management: Treasury Has Improved Short-Term Investment Programs, but Should Broaden Investments to Reduce Risks and Increase Returns. GAO-07-1105.

Hrung, Warren. 2007. “An Examination of Treasury Term Investment Interest Rates." Federal Reserve Bank of New York Economic Policy Review 13, no. 1 (March): 19-32.

Hrung, Warren, and Jason Seligman. 2011."Responses to the Financial Crisis, Treasury Debt, and the Impact on Short-Term Money Markets.” Federal Reserve Bank of New York Staff Reports, no. 481, January.

Investment Company Institute. 2009. Report of the Money Market Working Group.

Lang, Richard. 1979. “TTL Note Accounts and the Money Supply Process.” Federal Reserve Bank of St. Louis Review 61, no. 1 (October): 3-14.

Lovett, Joan. 1978. “Treasury Tax and Loan Accounts and Federal Reserve Open Market Operations.” Federal Reserve Bank of New York Quarterly Review 3, no. 2 (summer): 41-6.

Manypenny, Gerald D., and Michael L. Bermudez. 1992. “The Federal Reserve Banks as Fiscal Agents and Depositories of the United States." Federal Reserve Bulletin 78, no. 10 (October): 727-37.

McDonough, William. 1976. "New Policy Prompts Increased Defensive Operations by Federal Reserve." Federal Reserve Bank of Dallas Business Review, March: 8-12.

Special Inspector General for the Troubled Asset Relief Program. 2009. Initial Report to the Congress, February 6.

ABOUT THE AUTHORS

Paul J. Santoro is a senior financial/economic analyst in the Market Operations, Monitoring, and Analysis Function of the Federal Reserve Bank of New York's Markets Group.

Current Issues in Economics and Finance is published by the Research and Statistics Group of the Federal Reserve Bank of New York. Linda Goldberg and Thomas Klitgaard are the editors.

Editorial Staff: Valerie LaPorte, Mike De Mott, Michelle Bailer, Karen Carter, Anna Snider

Production: Carol Perlmutter, David Rosenberg, Jane Urry

Subscriptions to Current Issues are free. Send an e-mail to Research.Publications@ny.frb.org or write to the Publications Function, Federal Reserve Bank of New York, 33 Liberty Street, New York, N.Y. 10045-0001. Back issues of Current Issues are available at http://www.newyorkfed.org/research/current_issues/.

The views expressed in this article are those of the authors and do not necessarily reflect the position of the Federal Reserve Bank of New York or the Federal Reserve System. 


\section{RELATED READINGS FROM THE FEDERAL RESERVE BANK OF NEW YORK'S RESEARCH GROUP}

\section{Articles and Papers}

The Federal Reserve's Commercial Paper Funding Facility Tobias Adrian, Karin Kimbrough, and Dina Marchioni Economic Policy Review, vol. 17, no. 1, May 2011

Established in the wake of Lehman Brothers' bankruptcy to stabilize severe disruptions in the commercial paper market, the Commercial Paper Funding Facility allowed the Federal Reserve to act as a lender of last resort for issuers of commercial paper, thereby effectively addressing temporary liquidity distortions and alleviating the severe funding stress that threatened to further exacerbate the financial crisis. In doing so, the facility proved to be a noteworthy model of liquidity provision in a market-based financial system, where maturity transformation occurs outside of the commercial banking sector. This study examines the creation and performance of the facility, while outlining the evolution and importance of the commercial paper market.

The Federal Reserve's Primary Dealer Credit Facility Tobias Adrian, Christopher Burke, and James McAndrews Current Issues in Economics and Finance, vol. 15, no. 4, August 2009

As liquidity conditions in the "repo market" — the market where broker-dealers obtain financing for their securities - deteriorated following the near-bankruptcy of Bear Stearns in March 2008, the Federal Reserve took the step of creating a special facility to provide overnight loans to dealers that have a trading relationship with the Federal Reserve Bank of New York. Six months later, in the wake of new strains in the repo market, the Fed expanded the facility by broadening the types of collateral accepted for loans. Both initiatives were designed to help restore the orderly functioning of the market and to prevent the spillover of distress to other financial firms.

The Term Securities Lending Facility: Origin, Design, and Effects

Michael Fleming, Warren Hrung, and Frank Keane

Current Issues in Economics and Finance, vol. 15, no. 2, February 2009

The Federal Reserve launched the Term Securities Lending Facility (TSLF) in 2008 to promote liquidity in the funding markets and improve the operation of the broader financial markets. The facility increases the ability of dealers to obtain cash in the private market by enabling them to pledge securities temporarily as collateral for Treasuries, which are relatively easy to finance. The TSLF thus reduces the need for dealers to sell assets into illiquid markets and lessens the likelihood of a loss of confidence among lenders.
The Federal Reserve's Term Auction Facility Olivier Armantier, Sandra Krieger, and James McAndrews Current Issues in Economics and Finance, vol. 14, no. 5, July 2008

As liquidity conditions in the term funding markets grew increasingly strained in late 2007, the Federal Reserve began making funds available directly to banks through a new tool, the Term Auction Facility (TAF). The TAF provides term funding on a collateralized basis, at interest rates and amounts set by auction. The facility is designed to improve liquidity by making it easier for sound institutions to borrow when the markets are not operating efficiently.

Large-Scale Asset Purchases by the Federal Reserve: Did They Work?

Joseph Gagnon, Matthew Raskin, Julie Remache, and Brian Sack Economic Policy Review, vol. 17, no. 1, May 2011

This study reviews the Federal Reserve's experience in implementing large-scale asset purchases between late 2008 and March 2010. The authors show that by reducing the net supply of assets with long maturities, the purchases led to economically meaningful and long-lasting reductions in longer term interest rates on a range of securities. The reductions primarily reflect lower risk premiums, including term premiums. The asset purchase programs had an especially powerful effect on longer term interest rates on agency debt and agency mortgage-backed securities by improving market liquidity and removing assets with high prepayment risk from private portfolios.

The Introduction of the TMPG Fails Charge for U.S. Treasury Securities

Kenneth Garbade, Frank Keane, Lorie Logan, Amanda Stokes, and Jennifer Wolgemuth

Economic Policy Review, vol. 16, no. 2, October 2010

The TPMG fails charge for U.S. Treasury securities provides that a buyer of Treasury securities can claim monetary compensation from the seller if the seller fails to deliver the securities on a timely basis. The charge was introduced in May 2009 and replaced an existing market convention of simply postponing-without any explicit penalty and at an unchanged invoice price - a seller's obligation to deliver Treasury securities of the seller fails to deliver the securities on a scheduled settlement date. This article explains how a proliferation of settlement fails following the insolvency of Lehman Brothers Holdings Inc. in September 2008 led the Treasury Market Practices Group (TPMG), a group of market professionals committed to supporting the integrity and efficiency of the U.S. Treasury market, to promote a change in the existing market convention. The change - the introduction of the fails charge —-was significant 
because it mitigated an important dysfunctionality in the secondary market for U.S. Treasury securities and because it stands as an example of the value of cooperation between the public and private sectors in responding to altered market conditions in a flexible, timely, and innovative fashion.

Recent Innovations in Treasury Cash Management Kenneth Garbade, John Partlan, and Paul Santoro Current Issues in Economics and Finance, vol. 10, no. 11, November 2004

The Treasury Tax and Loan program, a joint undertaking of the Treasury and the Federal Reserve, is designed to manage federal tax receipts and stabilize the supply of reserves in the banking system. Three recent innovations-electronic collection of business taxes, real-time investment of excess Treasury balances, and competitive bidding for Treasury deposits-have materially enhanced the ability of the two agencies to achieve these objectives.

An Examination of Treasury Term Investment Interest Rates Warren Hrung

Economic Policy Review, vol. 13, no. 1, March 2007

In November 2003, the Term Investment Option (TIO) program became an official cash management tool of the U.S. Treasury Department. Through TIO, the Treasury lends funds to banks for a set number of days at an interest rate determined by a single-rate auction. One reason why the Treasury introduced TIO was to try to earn a market rate of return on its excess cash balances. This article studies 166 TIO auctions from November 2003 to February 2006 to determine how TIO interest rates have compared with market rates. The author investigates the spread between TIO rates and rates on mortgage-backed-security repos, a close benchmark for TIO rates. He finds that aside from offerings with very short-term lengths, the Treasury receives an interest rate on TIO auctions comparable to market rates. He also documents a negative relationship between an auction's size and the spread between TIO and repo rates. Furthermore, the Treasury's announcement and auctioning of funds on the same day does not adversely affect rate spreads, a finding that suggests that banks are indifferent to more advance notice of TIO auctions.

Responses to the Financial Crisis, Treasury Debt, and the Impact on Short-Term Money Markets

Warren Hrung and Jason Seligman

Staff Reports, no. 481, January 2011

Several programs have been introduced by U.S. fiscal and monetary authorities in response to the financial crisis. This study examines the responses involving Treasury debt-the Term Securities Lending Facility (TSLF), the Supplemental
Financing Program, increases in Treasury issuance, and open market operations - and their impacts on the overnight Treasury general collateral repo rate, a key money market rate. The authors' contribution is to consider each policy in light of the others, both to help guide policy responses to future crises and to emphasize policy interactions. Only the TSLF was designed to directly address stresses in short-term money markets by temporarily changing the supply of Treasury collateral in the marketplace. We find that the TSLF is uniquely effective relative to other policies and that, while changes in Treasury collateral do affect repo rates, the impacts are not equivalent across sources of Treasury collateral.

\section{Central Bank Dollar Swap Lines and Overseas Dollar Funding Costs \\ Linda Goldberg, Craig Kennedy, and Jason Miu Economic Policy Review, vol. 17, no. 1, May 2011}

In the decade prior to the financial crisis, foreign banks' exposure to U.S.-dollar-denominated assets increased dramatically. When the crisis hit in 2007, the banks' access to dollar funding came under severe constraints. The Federal Reserve responded in December 2007 by establishing temporary reciprocal currency swap lines with foreign central banks designed to ameliorate the dollar funding stresses overseas. Drawing on rigorous analysis of the swaps, as well as insights of other economic studies and anecdotal accounts of market participants, this article concludes that the lines were effective in reducing both dollar funding costs abroad and stresses in the money markets.

\section{Liberty Street Economics Blog Posts}

Innovations in Treasury Debt Instruments

Kenneth Garbade

April 9, 2012

Will "Quantitative Easing” Trigger Inflation?

Kenneth Garbade

June 8, 2011

Will the Federal Reserve's Asset Purchases Lead to

Higher Inflation?

Jamie McAndrews

May 18, 2011 